\title{
Planting Time Effects on the Productivity of Tef [Eragrostis tef (Zucc.) Varieties in Ethiopia
}

\author{
Bizuwork Tafes Desta ${ }^{*}$, Almaz Meseret Gezahegn, Sisay Eshetu Tesema \\ Ethiopia Institute of Agriculture Research, Debre Zeit Agricultural Research Center, Debre Zeit, Ethiopia
}

Email address:

b.tafes@gmail.com (B. T. Desta)

${ }^{*}$ Corresponding author

To cite this article:

Bizuwork Tafes Desta, Almaz Meseret Gezahegn, Sisay Eshetu Tesema. Planting Time Effects on the Productivity of Tef [Eragrostis tef (Zucc.) Varieties in Ethiopia. American Journal of Life Sciences. Vol. 8, No. 3, 2020, pp. 34-40. doi: 10.11648/j.ajls.20200803.11

Received: July 26, 2020; Accepted: August 5, 2020; Published: August 13, 2020

\begin{abstract}
In recent days there is change in trend of rainfall across the country where its starts in May and ceases early-tomid September. This implies that adjusting cropping calendar is vital to adapt to the changing climate of the area. The field experiments were carried out at Debre Zeit Agricultural Research Center (DZARC) and Alemtena during the main cropping season from 2015 to 2017 to determine appropriate sowing date for tef varieties. The treatments consisted of three sowing date (early-July, mid-July, and late-July) and two recently released tef varieties (Kora and Boset). The experiment was laid out in a randomized complete block design in a factorial arrangement and replicated four times per treatment. Data were taken crop growth, biomass yield, and grain yield. Combined analysis of variance overs years showed that interaction effects of variety by sowing date were significant effects on plant height and panicle length at DZAR while, at Alemtena, plant height and panicle length was significantly affected only by variety. At both location biomass and grain yield of tef was significantly affected by variety and sowing date interaction. Among the different sowing date treatments, sowing of Kora variety in mid-July showed the highest mean biomass yield $(8444.4 \mathrm{~kg} / \mathrm{ha}$ and grain yield $(1813.3 \mathrm{~kg} / \mathrm{ha})$ at DZARC but at Alemtena the highest biomass $(9766.2 \mathrm{~kg} / \mathrm{ha})$ and grain yield $(1595.7 \mathrm{~kg} / \mathrm{ha})$ was achieved Kora was sown in earl-July. However, sowing of Boset variety at mid-July was comparable yield advantages. Over all, based on the result of this study, sowing of mid-July and early-July would be recommended for the mentioned variety production at DZARC and Alemtena, respectively.
\end{abstract}

Keywords: Climate Change, Sowing Time, Tef, Yield

\section{Introduction}

Tef (Eragrostis tef (Zucc.) is the most important cereal crop in Ethiopia, where it is the first in terms of acreage and second after maize in grain production volume [1]. The crop is preferred both by farmers and consumers. Farmers benefit since it can be produced under diverse agro-ecological conditions and can be stored for a long time as the grains not affected by storage pests [2]. For a cereal, tef grains are highly nutritious and its nutritional content is generally comparable to that of the major world cereals like wheat, barley, rice, maize and sorghum [3, 4]. The grain nutrition comprises well-balanced protein and is high mineral composition ([3, 5, 6]. Moreover, its high iron content is associated with the low prevalence of hook-worm [7] and pregnancy related anemia in people consuming tef as staple food. The importance of tef straw has been becoming as equal as its grain yield as it is preferred as animal feed during dry period and also sold at reasonable price [8]. In general, tef plays a vital role in food security, nutrition and income generation to resource poor farmers in Ethiopia [9]. It serves both as a staple and cash crop and recently it is gaining more attention in the world market mainly because the grains are free from gluten to which many people are allergic [10].

Over more than six past decades of tef research in Ethiopia, particularly Debre Zeit Agricultural Research center (DAZRC), appreciable progress has been made and commendable achievements have been registered in improving the production and productivity of tef [11]. Appropriate crop management practices can have strong impacts on crop productivity, sustainability, and profitability under any specific growth conditions. One of the requirements for obtaining high yield is the choice of the suitable sowing date and there are enough possibilities to 
increase crop yields through developing new high yielding varieties and by adopting proper sowing date [12].

Tef production activity calendar varies from location to location, and its production takes place mainly during the long (Meher) rainy season. Tef sowing starts from end of June and extends to early September depending on growing length of particular location and beginning of rainfall [13]. However, in most places, tef may be sown between mid-July and earlyAugust [14]. This cropping calendar was adopted when appreciable amount of rainfall received in the month of September and the first two-weeks of October and still practiced despite of great departure of rainfall from normal distribution due to global climate change [15]. In recent days there is change in trend of rainfall across the country where its starts in May and ceases early- to- mid September [16, 17]. This early cease of rainfall matches crop's reproductive stages, stages most sensitive to water deficit, with periods of water shortage. Coincidence of water deficit sensitive developmental stages of crop with soil moisture deficit causes both quantity and quality loss to the final yield [8].

Date of sowing has a profound influence on crop performance because it determines the kind of environmental conditions to which the various phenological stages of the crop will be exposed. This implies that adjusting cropping calendar is vital to adapt to the changing climate of the area. Currently, only few farmers adjust their sowing time in response to perceived climate change as they have no access to information based on long term data [19]. Under such situations, the cropping calendar of farmers remains as it is despite change in timing of rainfall. Of this, the present study was designed with the objectives to determine best sowing date allied with onset, end set and length of growing period that can increase productivity of tef varieties.

\section{Materials and Methods}

The experiments were conducted at Debre Zeit Agricultural Research Center (DZARC) and Alemtena which is the sub site of DZARC, in Ethiopia three consecutives (2015, 2016 and 2017) cropping seasons under rain fed condition. The DZARC has high potential for tef production, and its geographical location is $8^{\circ} 44^{\prime} \mathrm{N}$ latitude and $38^{\circ} 58^{\prime} \mathrm{E}$ longitude. The altitude is about 1900 meter above sea level while, the majority of trial fields are heavy soils (Vertisol) with few pockets of light soils (Alfisols/Mollisols) [20]. Rainfall was erratic and lower distributed over the crop growing season in 2015 with $518.1 \mathrm{~mm}$ compared with in 2016 with $652.4 \mathrm{~mm}$ and in 2017 with $721.6 \mathrm{~mm}$ at DZARC (Figure 1).

Alemtena has low potential for tef production and is located at $8^{\circ} 30^{\prime}$ '57.6" $\mathrm{N}$ and 39 95'10.6" E longitude with 1611 meter elevation. The soil order was Andisols (Typic Haplustand) with low wet aggregate stability, a propensity for crusting [21]. Seasonal rainfall during tef growing months at Alemtena was $555.6 \mathrm{~mm}$ in 2015, $565.7 \mathrm{~mm}$ in 2016 and $1207.97 \mathrm{~mm}$ in 2017 of (Figure 2). There was low rainfall during tef grain filling period (September) in the two years (in 2015 and 2016) compared with in 2017 at this location (Figure 2).

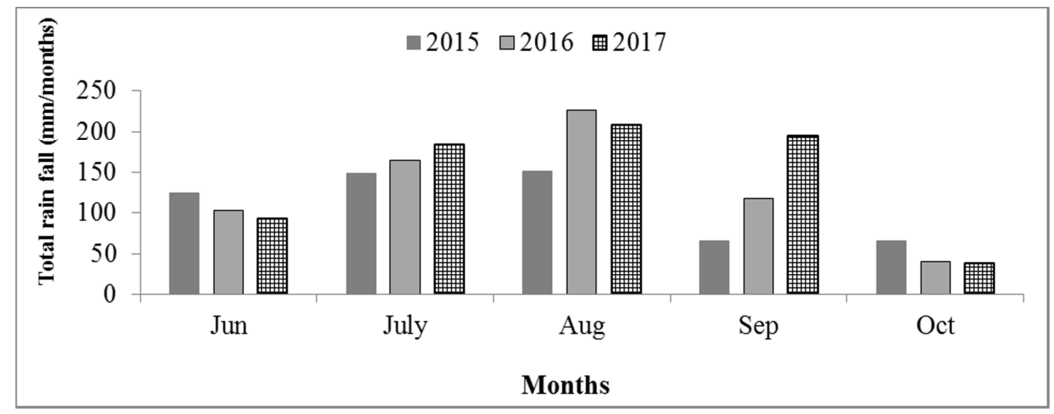

Figure 1. Total precipitation in tef growing seasons at DZARC from 2015 to 2017.

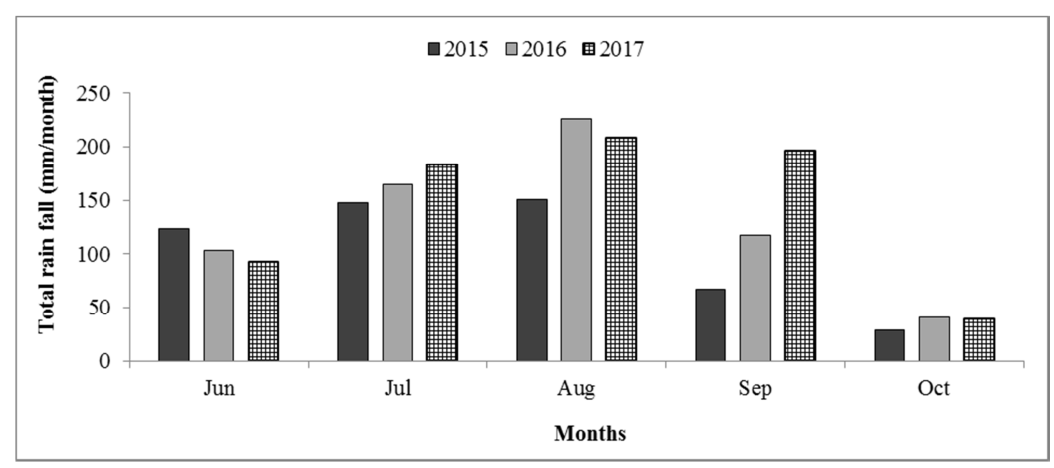

Figure 2. Total precipitation in tef growing seasons at Alemteana from 2015 to 2017.

\subsection{Treatments, Design and Field Management}

The treatments were consisted of two tef varieties called Kora and Boset and three sowing date via; early-July ( $1^{\text {st }}$ July), midJuly ( $15^{\text {th }}$ July) and late-July ( $30^{\text {th }}$ July). The experiment was laid out in a randomized complete block design in a factorial 
arrangement and replicated four times per treatments. Each experimental unit consisted of fifteen rows with distances of 20 $\mathrm{cm}$ and lengths of $3 \mathrm{~m}$. The net central unit areas of each plot consisting of eight central rows of $2.80 \mathrm{~m}$ long were harvested and used for yield determination. The seeds was sown with hand drilling at the rate of $10(\mathrm{~kg} / \mathrm{ha})$ in $20 \mathrm{~cm}$ rows space. Recommended rate of $100 \mathrm{~kg} \mathrm{DAP} / \mathrm{ha}$ full dose at planting and $125 \mathrm{~kg}$ and $50 \mathrm{~kg}$ urea/ha for DZARC and Alemtena, respectively, two split, 1/3 at sowing and 2/3 at tillering was applied.

\subsection{Data Collection}

Observation was made on plant height, panicle length, aboveground biomass yield $\mathrm{kg} / \mathrm{ha}$ and grain yield $\mathrm{kg} / \mathrm{ha}$. Plant height: At maturity, ten effective tiller plants were taken randomly from the net plot area of each plot and height was measured from the ground to the tip of tillers using ruler and the mean value were determined in $\mathrm{cm}$. Productive tillers: Productive tillers (effective tillers) were determined at maturity by counting all the productive (head bearing) tillers in one $\mathrm{m}$ length row taken from five rows $(1 \mathrm{~m}$ wide) in each net plot area and then converted to $\mathrm{m}^{2}$. Panicle length: At maturity, ten panicles from the effective tillers were taken randomly from the net plot area of each plot and measured from the bottom of the panicle to the tip of the head and then, the mean value was determined in $\mathrm{cm}$. Aboveground biomass yield: At maturity, the whole aboveground plant parts, including leaves, stems, and seeds from the net plot area in each plot was harvested and sun dried until a constant weight and then the aboveground biomass was weighed and then expressed in $\mathrm{kg} \mathrm{ha}^{-1}$. Grain yield (GY): After harvesting, threshed grains were separated, cleaned and weighed by electronic balance. The grain yield was corrected to moisture content of $12.5 \%$, wet bases while moisture tester was employed for measuring the moisture content. Soil samples for determination of soil moisture content were collected for the $0-0.30 \mathrm{~cm}$ soil profile before/just at planting of the crop for each sowing dates. Soil was weighed fresh in aluminum tins, dried at $105^{\circ} \mathrm{C}$ to a constant weight, and weighed dry from which the weight of water and dry soil dry weight mass were determined. The gravimetric water content (kg kg-1) was calculated by dividing the weight of water by the dry soil weight [22].

\subsection{Statistical Data Analysis}

The data were subjected to combined analysis of variance (ANOVA) over years after confirmation of homogeneity of error variance using $\mathrm{R}$ software program while separate analyses were conducted for each location because of heterogeneity of error variance. The means were compared by LSD method at 0.05 probability level.

\section{Results and Discussion}

\subsection{Soil Moisture Contents at Different Planting Times}

Soil moisture content during planting at DZARC was lower in early-July compared with mid and late July in 2015 to 2017 years, on the other hand soil moisture content was more in mid and late-July (Figure 3). At Alemtena, soil moisture content was more in mid-July, but the trend was not consistent in late-July (Figure 4).

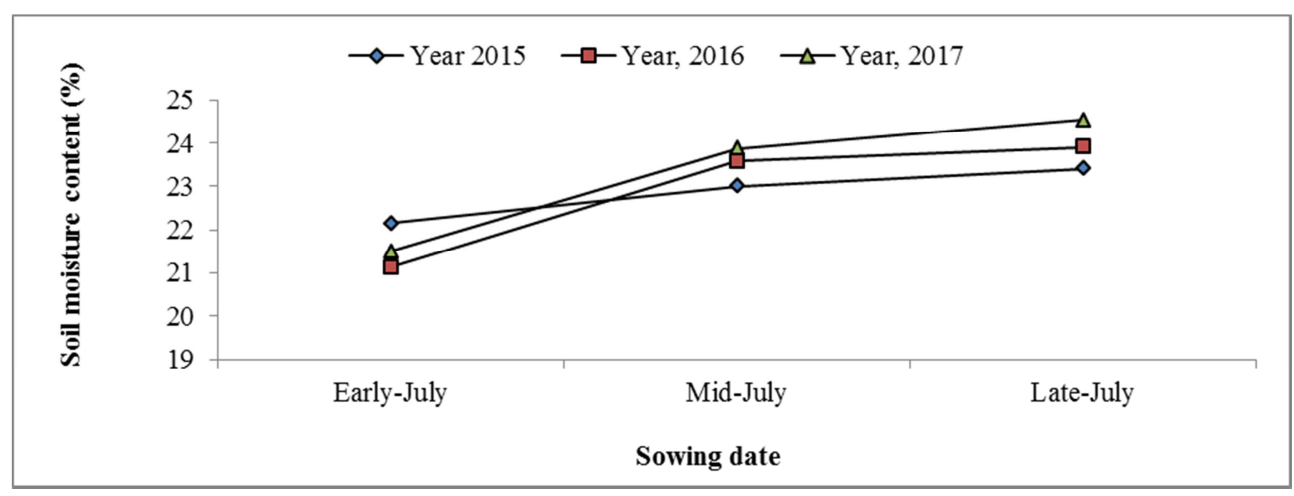

Figure 3. Mean of soil moisture content during different tef sowing time at DZARC.

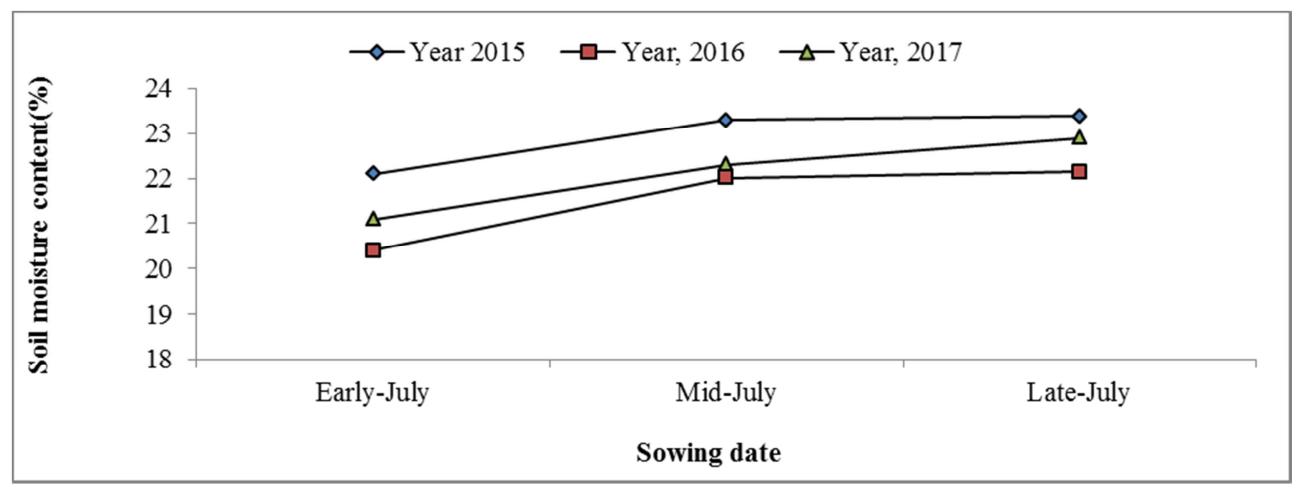

Figure 4. Means of soil moisture content during different tef sowing time at Alentena. 


\subsection{Plant Height and Panicle Length}

The results regarding the plant height and panicle length of tef, its effects of sowing date and variety at DZARC and Alemtena from 2015 to 2017 cropping seasons are presented in Tables 1 and 2 , respectively. The combined analysis of variance over the three years $(2015,2016$ and 2017) revealed that highly significant $(p<0.01)$ difference among sowing dates and the interaction effects of the two factors (sowing date $\mathrm{x}$ variety) on above traits at DZARC (Table 1) but in case of Alentena, significant $(\mathrm{p}<0.01)$ difference was observed only by varieties (Table 2 ).

At DZARC, it is evident from the result that the tallest plant height $(120.58 \mathrm{~cm})$ and panicle length $(46.68 \mathrm{~cm})$ was obtained when Kora was sown in mid-July followed by when the variety was sown late-July, plant height $(118.02 \mathrm{~cm})$ and panicle length $(44.94 \mathrm{~cm})$ (Table 1). In contrast to this result, [23] reported that sowing date showed significance difference on plant height and panicle length of tef when the crop was sown in early-July (on 2 July). On the other hand, sowing of tef varieties in early-July were fewer seedlings emerged. The possible reason is insufficient soil moisture in early-July planting periods (Figure 3). Tef can be sown during a season when the rainfall is reliable and well wet soil on Vertisol than Andousol [24].

Table 1. Mean plant height and panicle length of tef as influenced by interaction effects of sowing date and variety at DZARC 2015 to 2017 cropping season.

\begin{tabular}{llll}
\hline \multirow{2}{*}{ Variety } & \multirow{2}{*}{ Sowing date } & \multicolumn{2}{l}{ DZARC } \\
\cline { 3 - 4 } & & PH $(\mathbf{c m})$ & PL $(\mathbf{c m})$ \\
\hline \multirow{3}{*}{ Kora } & Early-July & $117.13 \mathrm{ab}$ & $43.5 \mathrm{ab}$ \\
& Mid-July & $120.58 \mathrm{a}$ & $46.7 \mathrm{a}$ \\
& Late-July & $118.02 \mathrm{a}$ & $44.9 \mathrm{a}$ \\
\multirow{3}{*}{ Boset } & Early-July & $89.23 \mathrm{~d}$ & $34.2 \mathrm{~d}$ \\
& Mid-July & $99.79 \mathrm{~b}$ & $39.2 \mathrm{~b}$ \\
& Late-July & $93.60 \mathrm{~cd}$ & $35.2 \mathrm{~cd}$ \\
& LSD & 3.29 & 1.99 \\
& CV & 4.52 & 7.12 \\
\hline
\end{tabular}

$\mathrm{PH}=$ plant height; $\mathrm{PL}=$ panicle length; Means with the same letter in columns are not significantly different at $5 \%$ level of significance; LSD= least significant differences at $5 \% ; \mathrm{CV}(\%)=$ Coefficient of variation.
At Alemtena, a significant difference was observed only by variety. The tallest plant height $(105.59 \mathrm{~cm})$ and panicle length $(41.99 \mathrm{~cm})$ was recorded from the Kora variety while, the shortest plant height $(85.87 \mathrm{~cm})$ and panicle length $(33.75 \mathrm{~cm})$ was obtained from the Boset variety (Table 2$)$. The significant difference among the varieties for these growth traits might be attributed to their genetic difference which reflects their different response to environmental conditions. Plant height of the crop is mainly controlled by the genetic makeup of a genotype and it can also be affected by the environmental factors [25].

Table 2. Mean plant height and panicle length of tef as influenced by main effects of sowing date and variety at Alemtena 2015 to 2017 cropping seasons.

\begin{tabular}{lll}
\hline \multirow{2}{*}{ Variety } & Treatment & AlenTena \\
\cline { 2 - 3 } & PH $(\mathbf{c m})$ & PL $(\mathbf{c m})$ \\
\hline Kora & $105.59 \mathrm{a}$ & $41.99 \mathrm{a}$ \\
Boset & $85.87 \mathrm{~b}$ & $33.75 \mathrm{~b}$ \\
LSD & 4.84 & 2.40 \\
Early-July & 96.63 & 38.12 \\
Mid-July & 96.80 & 37.53 \\
Late-July & 93.76 & 37.96 \\
LSD (0.05) & NS & NS \\
CV $(\%)$ & 8.55 & 10.70 \\
\hline
\end{tabular}

$\mathrm{PH}=$ plant height; $\mathrm{PL}=$ panicle length; Means with the same letter in columns are not significantly different at $5 \%$ level of significance; LSD= least significant differences at $5 \%$; CV $(\%)=$ Coefficient of variation.

\subsection{Biomass Yield}

Aboveground biomass yield of tef crop is the combined effect of various yields contributing components viz. more number of tillers $\mathrm{m}^{-2}$, plant height, number of florets per head and panicle length ${ }^{1}$. Combined analysis of variance over three years reviled that significant $(\mathrm{P}<0.001)$ difference among sowing date, variety and the interaction effect of the two factors on the aboveground biomass yield of tef (Figures 5 and 6).

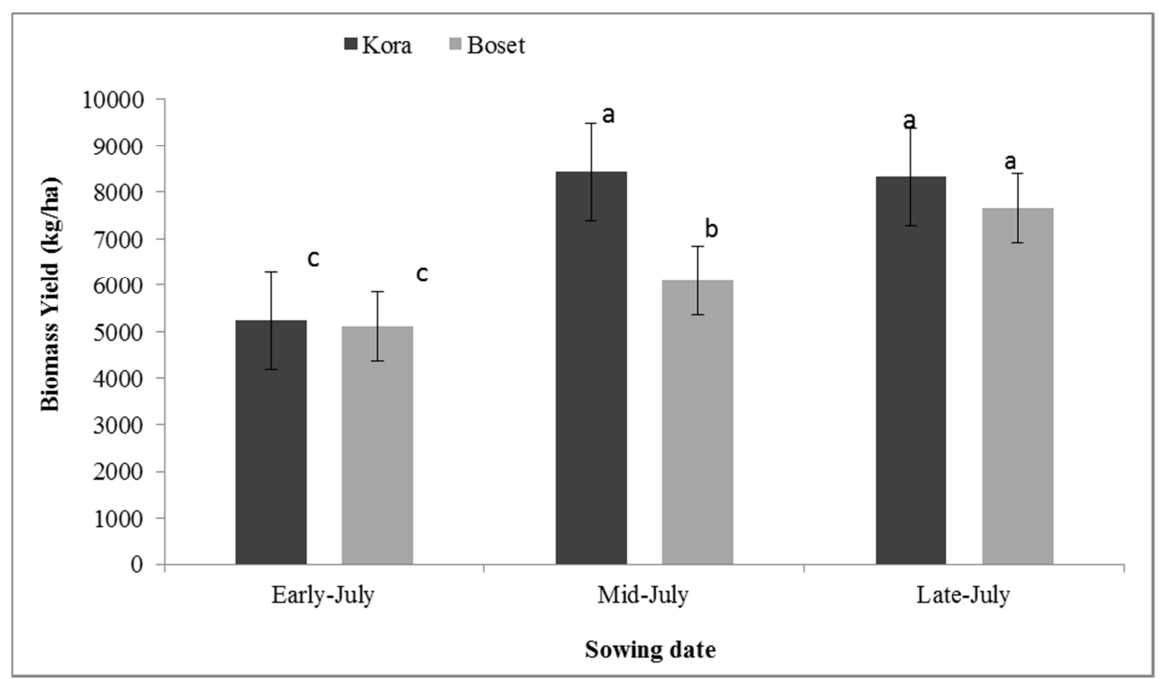

Figure 5. The interaction effect of planting date and variety on the biomass yield ( $\mathrm{kg} / \mathrm{ha}$ ) of tef at DZARC, Ethiopia. 


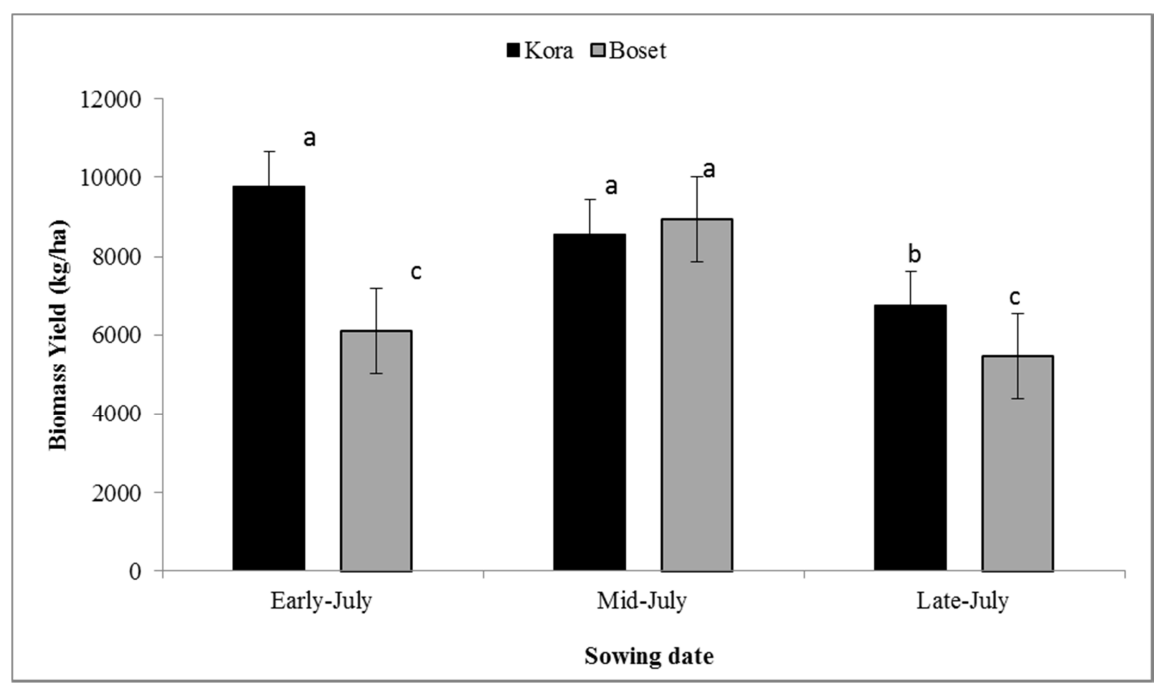

Figure 6. The interaction effect of planting date and variety on the biomass yield $(\mathrm{kg} / \mathrm{ha}$ ) of tef at Alemtena, Ethiopia.

At DZARC, the highest aboveground dry biomass yield $(8444.4 \mathrm{~kg} / \mathrm{ha})$ was noted when Kora variety was sown in mid-July, closely followed by sown in late-July (8333.3 $\mathrm{kg} / \mathrm{ha}$ ). Similarly, previous study tef may be sown between mid-July and early-August in Vertisol produced higher biomass yield [26]. On the other hand, early sowing (earlyJuly), both Kora and Boset was fewer seedling emerged during the experimental seasons (Figure 5). The reason might be due to insufficient soil moisture for tef germination in early-July planting (Figure 3). Contrary to DZARC, at Alemtena the highest aboveground dry biomass yield (9766.2 $\mathrm{kg} / \mathrm{ha}$ ) was recorded when Kora was sown early-July which was statistically identical with Boset variety sown in midJuly (8947.2 kg/ha (Figure 6). In agreement with present result, when sowing dates were delayed by one and two weeks, the biomass yields were reduced by $35 \%$ [27].

\subsection{Grain Yield}

Combined analysis of variance over three years (from 2015 to 2017) showed that sowing date, variety and interaction effect of the two factors were significantly $(\mathrm{P}<0.05)$ influenced grain yield at both locations (DZARC and Alemtena).

At DZARC, significantly maximum grain yield (1813.3 $\mathrm{kg} / \mathrm{ha}$ ) was obtained when Kora was sown in mid-July which was statistically at par sown in late-July $(1698.9 \mathrm{~kg} / \mathrm{ha})$ (Figure 7). At Alemtena, the highest grain yield (1595.7 $\mathrm{kg} / \mathrm{ha}$ ) was noted Kora was sown in early-July followed by Boset sown in mid-July (1499.1 kg/ha) (Figure 8). At Alemtena, the lowest grain yield $(1066.7 \mathrm{~kg} / \mathrm{ha})$ from Kora and $(917.6 \mathrm{~kg} / \mathrm{ha})$ from Boset was obtained when sown in late-July (Figure 8). In the present experiment, tef variety Kora was sown early-July at Alem Tena showed a comparable yield than Boset variety when sown in earlier. The possible reason might be due to Kora variety is late maturity type but Boset is early maturity that is why, Kora was gave comparable yield when sown in early. There was similar result was reported to the current finding earlysowing of late maturity variety is relatively better yield advantage on Inceptisols [28].

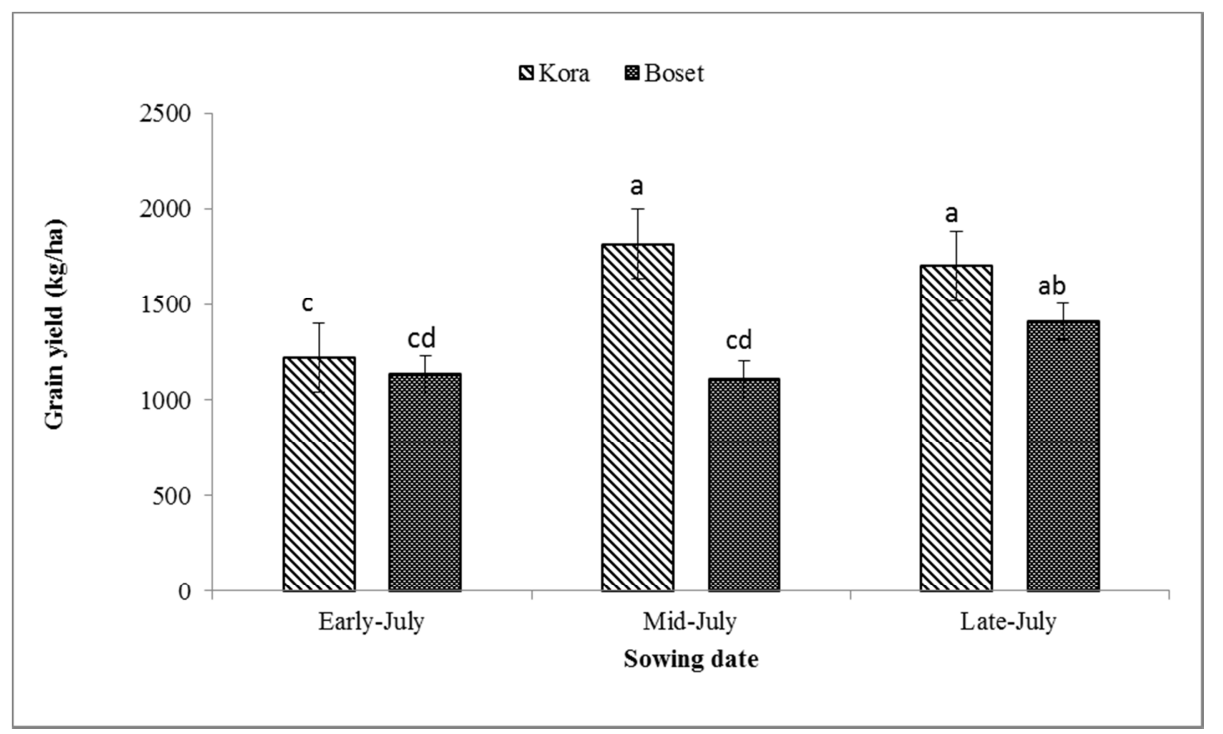

Figure 7. The interaction effect of planting date and variety on the grain yield $(\mathrm{kg} / \mathrm{ha})$ of tef at DZARC, Ethiopia. 


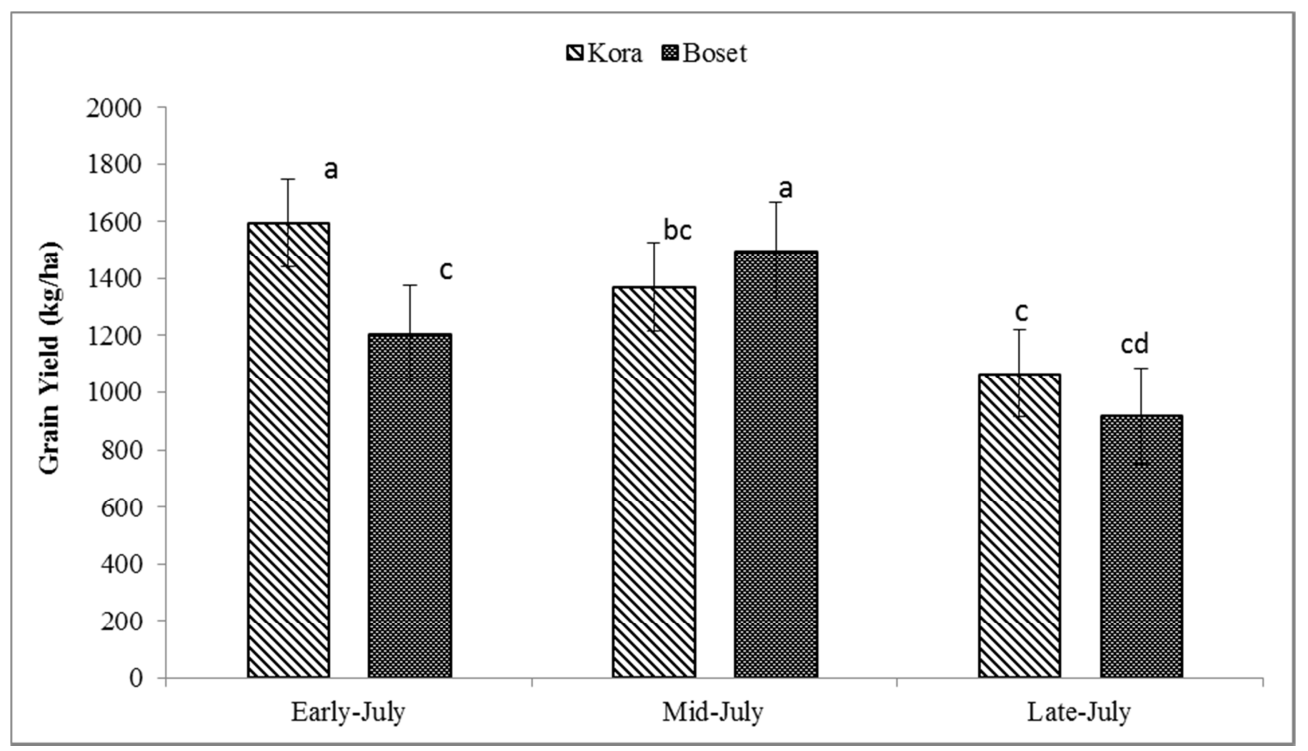

Figure 8. The interaction effect of planting date and variety on the grain yield $(\mathrm{kg} / \mathrm{ha}$ ) of tef at Alemtena, Ethiopia.

\subsection{Percentile Description of Onset, End Date, Length of Growing Duration of the Season}

The occurrence of rainy seasons was carried out based on frequency analysis of 30 years (1987-2017). The onset, end date and length of growing period at DZARC and Alemtena daily weather data are presented in Table 3. Onset of rainy seasons occurred before 1st dekad of June (06-Jun) was $25 \%$ while it occurred before 3rd dekad of July (08-July) in $75 \%$ with coefficient of variation (CV) of $4.8 \%$ at DZARC. The end date of the rain season at DZARC, $75 \%$ of the last 30 years showed that on 12-October and the length of growing period (LGP) 111 days. At Alemtena, the onset of rain season out of the 30 year $25 \%$ was on $02-$ June and $75 \%$ on June- 24 . The $75 \%$ of end date was laid 20 -September and the LGP was shorter (92 days) compared with DZARC. This implies that Alemtena was early onset and shorter LGP. Though early planting is better, while at DZARC relatively let onset and longer LGP, planting in mid-July is appropriate when soil is wet.

Table 3. Summary of Onset, offset and length of growing period (LGP) for 30 years (1990 to 2017) at DAZRC and Alemtena.

\begin{tabular}{|c|c|c|c|c|c|c|}
\hline \multirow{2}{*}{ Statistical parameter } & \multicolumn{3}{|l|}{ DZARC } & \multicolumn{3}{|c|}{ Alemtena } \\
\hline & Onset & End date & LGP & Onset & End date & LGP \\
\hline Minimum & 25-Jun & 28-Sep & 61 & 01-Jun & 16-Sep & 68 \\
\hline Quartile $1(25 \%)$ & 29-Jun & 28-Sep & 84 & 02-Jun & 26-Sep & 100 \\
\hline Quartile $2(50 \%)$ & 06-July & 30-Sep & 92 & 18-Jun & 06-Oct & 108 \\
\hline Quartile 3 (75\%) & 08-July & 12-Oct & 111 & 24-Jun & 20-Sep & 92 \\
\hline Maximum & 29-July & $11-$ Oct & 139 & 19-Jul & 23-Oct & 131 \\
\hline Mean & 06-July & 06-Oct & 92 & 16-Jun & 03-Oct & 121 \\
\hline $\mathrm{SD}$ & 9.08 & 10.99 & 16.8 & 13.37 & 8.65 & 14.39 \\
\hline $\mathrm{CV}(\%)$ & 4.8 & 3.9 & 18.2 & 7.96 & 3.12 & 13.32 \\
\hline
\end{tabular}

\section{Conclusion}

The highest grain yield and yield component of biomass yield, panicle length and plant height were recorded Kora variety was sown in mid-July at DZARC and early sowing at Alemtena whereas Boset sown in mid-July at Alemtena was also significant yield advantages than delayed sowing (lateJuly). Finally, we recommended that, mid-July to late-July at DZARC and early-July at Alemtena appropriate sowing date for Kora variety. On the other hand, sowing in mid-July is appropriate for Boset variety at Alemtena and similar agroecology.

\section{References}

[1] CSA (Central Statistical Agency) (2019). Agricultural Sample Survey 2016/2017 Agricultural Sample Survey. Agricultural sample survey, report on area and production of major crops, Addis Ababa, Ethiopia.

[2] Hailu, T. A., \& Seyfu, K. (2001). Production and Importance of Tef in Ethiopia Agriculture. In T. Hailu, B. A. Getachew, \& S. Mark (Eds.), Tef research and development. Proceedings of the International Workshop on Tef Genetics and Improvement (pp. 3-7). DebreZeit, Ethiopia. 2000 October 16-19. Addis Abeba: Ethiopian Institute of Agricultural Research (EIAR). 
[3] Agren and Gibson (1968). Chemical composition of tef as compared to that of wheat, barley and grain sorghum. Economic Botany, 20 (3): 268-273.

[4] Melak-Hail Mengesha (1966). Chemical composition of teff as compared to that of wheat, barley and grain sorghum. Economic Botany, 20 (3): 268-273.

[5] Bultosa Geremew (2007). Physicochemical Characteristics of Grain and Flour in 13 Tef [Eragrostis tef (Zucc.) Trotter] Grain Varieties. Journal of Applied Sciences Research, 3 (12): 2042-2051.

[6] Baye, K. (2018) Tef: nutrient composition and health benefits, ESSP Working Paper 67, Washington, D. C. and Addis Ababa, Ethiopia.

[7] Ethiopian Nutrition Survey (1959). A Report by InterDepartmental Committee on Nutrition for National Defense, ENS, Addis Ababa, Ethiopia.

[8] Dejene, K. 2009. The influence of soil water deficit imposed during various developmental phases on physiological processes of tef (Eragrostis tef). Agriculture, Ecosystems and Environment, 132, 283-289.

[9] Berhanu, A. (2004). The food security role of agriculture in Ethiopia. Journal of agricultural Development and Economics, 1 (1): Pp. 138-153.

[10] Spaenij-Dekking L, Kooy-Winkelaar Y, Koning F. (2005). The Ethiopian cereal tef in celiac disease. Engl J Med, 353: 1748-1749.

[11] Assefa K, Chanyalew S, Tadele Z. (2013). Achievements and Prospects of Tef Improvement-Proceedings of the Second International Workshop, November 7-9, 2011, Debre Zeit, Ethiopia. Ethiopian Institute of Agricultural Research, Addis Ababa, Ethiopia; Institute of Plant Sciences, University of Bern, Switzerland.

[12] Aslani F, Mehrvar MR. (2012). Responses of wheat genotypes as affected by different sowing dates. Asian Journal of Agricultural Sciences, 4: 72-74.

[13] Kenea, Y., Gezahegn, A. and Workneh, N. (2000). Farming Systems Research on Tef: Smallholders' production practices. Hailu, T., Getachew, B. and Sorrells, M. (eds.). Narrowing the Rift: Tef Research and Development. Proceeding of the international workshop on Tef genetics and improvement, 1619 October 2000, Addis Ababa, Ethiopia.

[14] Yilma, S. and Cajuste, J. (1980). Tef production guideline. Published by IAR Extension and Liaison Department, Addis Ababa, Ethiopia.

[15] BFS/USAID. (2017). Climate-Smart Agriculture in Ethiopia. CSA Country Profiles for Africa Series. International Center for Tropical Agriculture (CIAT); Bureau for Food Security, United States Agency for International Development (BFS/USAID), Washington, D. C. 26 p.

[16] Murphy C. (2014). Observed and projected climate change in the Philippines, Honduras, Kenya, Malawi and Ethiopia. Department of Geography, Maynooth University and Mavuto Tembo, Mzuzu Unviersity, Malawi. Available at: http://bit.ly/2id29YL.
[17] USAID (2015). Climate variability and change in Ethiopia. Summary report. United States Agency for International Development (USAID).

[18] Dejene K. Mengistu and Lemlem S. Mekonnen (January 25th 2012). Integrated Agronomic Crop Managements to Improve Tef Productivity Under Terminal Drought, Water Stress, Ismail Md. Mofizur Rahman and Hiroshi Hasegawa, Intech Open, DOI: 10.5772/30662. Available. from: https:/www.intechopen.com/books/water-stress/integratedagronomic-crop-managments-to-improve-tef-productivityunder-terminal-drought.

[19] Elizabet, B., Temesgen, D., Gbetibouo, G. and Ringler, C. (2009). Adaptation to climate change in Ethiopia and South Africa: Options and Constraints. Environmental Science and Policy, 12: 413-426.

[20] WRB (World Reference Base) (2006). A framework for international classification, correlation and communication, world soil resource report 103, Rome, p68.

[21] Mesfin, T., J. Mohammed, A. Taklete, F. Merga, and C. S. Wortmann (2014). Skip-row planting of maize and sorghum production in semi-arid Ethiopia. Afr. J. Plant Sci. 8: 140-146. Doi: $10.5897 /$ AJPS2013.1137.

[22] Black, C. A. (1965). Methods of soil analysis: Part I physical and mineralogical properties. ASA, Madison, WI.

[23] Jambere T. (2016). Reducing land Degradation and Farmers' Vulnerability to Climate Change in the Highland and Dry areas of North-Western Ethiopia. Technical Report of Experimental Activities. June, 2013 to January, 2014.

[24] Ketema S. (1997). Tef [Eragrostis tef (Zucc.) Trotter]. Promoting the Conservation and Use of Underutilized and Neglected crops. International Plant Genetics Resources Institute (IPGRI), Biodiversity Institute, Addis Ababa, Ethiopia. $50 \mathrm{pp}$.

[25] Shahzad, M A., Din, W. U. Sahi, S. T. Khan M. Ehsanullah M. and. Ahmad, M. (2007). Effectof sowing dates and seed treatment on grain yield and quality of wheat. Pakistan Journalof Agricultural Science, 44 (4): 581-583.

[26] Seyoum Y., and Cajuste J. (1980). Tef production guideline. Published by IAR Extension and Liaison Department, Addis Ababa, Ethiopia.

[27] Juraimi A. S, Begum M., Ahmed M. Sherif and Rajan A. (2009). Effects of sowing date and nutsedge removal time on plant growth and yield of tef [Eragrostis tef (Zucc.) Trotter]. African Journal of Applied Sciences, 6 (10): 1820-1825.

[28] Ketema S. (1989). Copping systems, production technology, pests, diseases, utilization and forage use of millets with special emphasis on tef in Ethiopia. Page 309-314. In seetharam, A., K. w. small millets in Global Agriculture. Proceedings of the first Intentional small millets workshop, Banglore, India, October 29-November 2, 1986, oxford and IBH publishing co. PVT. LTD, New Delhi, India. 